\title{
A re-examination of the pathway for ornithine biosynthesis in a thermophilic and two mesophilic Bacillus species
}

\author{
Vehary Sakanyan, ${ }^{1}$ Anahit Kochikyan, ${ }^{1}$ Igor Mett, ${ }^{1}$ Christianne Legrain, ${ }^{2 *}$ \\ Daniel Charlier, ${ }^{2}$ ANDré PiÉrard ${ }^{2,3}$ and Nicolas GlansDorfF ${ }^{2,4}$
}

\author{
1 Pharmagen, Knunyantsstr. 4, Yerevan 375010, Republic of Armenia \\ ${ }^{2}$ Research Institute, CERIA-COOVI, 1 avenue Emile Gryson, B-1070 Brussels, Belgium \\ ${ }^{3}$ Laboratoire de Microbiologie, Université Libre de Bruxelles, Belgium \\ ${ }^{4}$ Laboratorium voor Erfelijkheidsleer en Microbiologie, Vrije Universiteit Brussel, Belgium
}

(Received 15 August 1991; accepted 24 August 1991)

\begin{abstract}
The expression of Bacillus stearothermophilus genes complementing arginine auxotrophs of Escherichia coli was studied. The activity responsible for the formation of ornithine in $B$. stearothermophilus was identified as a repressible ornithine acetyltransferase (genetic symbol $\arg J$ ) encoded by the same DNA fragment as the $\arg C$, $\arg A$ and $\arg B$ genes. Bacillus subtilis and Bacillus licheniformis displayed the same pattern of enzyme activities as $B$. stearothermophilus. In contrast to previous reports, these organisms consequently use the cyclic pathway of ornithine biosynthesis. B. stearothermophilus also possesses a broad specificity aminoacylase which exhibits low affinity towards $N^{2}$-acetyl-L-ornithine.
\end{abstract}

\section{Introduction}

In micro-organisms, ornithine (a precursor of arginine) is synthesized from glutamate via $\mathrm{N}$-acetylated intermediates (Fig. 1). The deacylation of acetylornithine can be achieved in two different ways: a linear pathway in which the formation of ornithine is mediated by the hydrolytic enzyme acetylornithinase (Fig. 1, step 5), or a cyclic pathway in which the acetyl group is recycled by transacetylation (Fig. 1, step $5^{\prime}$ ). The linear pathway is characteristic of the Enterobacteriaceae (Vogel \& Bonner, 1956). It has also been found in the thermophilic archaeobacterium Sulfolobus solfataricus (Van de Casteele et al., 1990). The same linear pathway was supposed to be used by the Gram-positive Bacillaceae (Vogel \& Vogel, 1963; Udaka, 1966). Other prokaryotes, including several methanogenic archaeobacteria (Meile \& Leisinger, 1984; Van de Casteele et al., 1990), and all eukaryotic microbes (Davis, 1986) have been found to recycle the acetyl group by transacetylation of $N$ acetylornithine and glutamate. The expression in Escherichia coli of several arginine genes from mesophilic heterologous hosts has been reported (Mountain et al., 1984; Jeenes et al., 1986; Picard \& Dillon, 1989). Complementation of $E$. coli auxotrophs by DNA from the thermophilic Gram-positive bacterium Bacillus stearothermophilus was reported recently (Sakanyan et al., 1990).
In this work we have analysed the expression of $\mathrm{arg}$ genes from $B$. stearothermophilus in $E$. coli $\mathrm{K} 12$. The results led us to re-examine the status of the ornithine biosynthetic pathway in bacilli.

\section{Methods}

Bacterial strains and plasmids. These are listed in Table 1. The RecA derivative of $E$. coli $\mathrm{K} 12$ strain XS1 D2 was obtained by selection of $\mathrm{Tc}^{\mathrm{r}}$ UV-sensitive recombinants after conjugation with the donor strain $E$. coli K12 NK 6659. The $\arg E$ derivative of XA4 was obtained by transduction with phage Pl grown on strain BW6165 and selection for Tc resistance.

Media and growth conditions. $E$. coli strains were grown at $37^{\circ} \mathrm{C}$ in Lbroth medium and in synthetic M9 (Maniatis et al., 1982) or 132 medium (Falmagne et al., 1965). Concentrations of antibiotics (in $\mu \mathrm{g}$ $\mathrm{ml}^{-1}$ ) were: ampicillin (Ap), 100, and tetracycline hydrochloride (Tc), 30. B. stearothermophilus was grown at $55^{\circ} \mathrm{C}$ in L-broth medium or in the defined AUF medium (Piérard \& Wiame, 1964) supplemented with $25 \mathrm{~mm}$-glucose, $5 \mathrm{~mm}-\left(\mathrm{NH}_{4}\right)_{2} \mathrm{SO}_{4}$ and $0.1 \%(\mathrm{v} / \mathrm{v})$ Nitsch's trace element solution (Ramaley \& Hixson, 1970). B. subtilis and $B$. licheniformis were grown at $37^{\circ} \mathrm{C}$ in liquid mineral medium 154 (Stalon et al., 1967) supplemented with $25 \mathrm{~mm}$-glucose and $5 \mathrm{~mm}-\left(\mathrm{NH}_{4}\right)_{2} \mathrm{SO}_{4}$.

Transformation of bacteria. $E$. coli cells were grown to midexponential phase and made competent for transformation by standard $\mathrm{CaCl}_{2}$ treatment (Dagert \& Ehrlich, 1979).

$D N A$ isolation and restriction. Isolation of plasmid DNA was carried out by the method of Birnboim \& Doly (1979). Plasmid DNAs were manipulated according to classical protocols (Maniatis et al., 1982). 


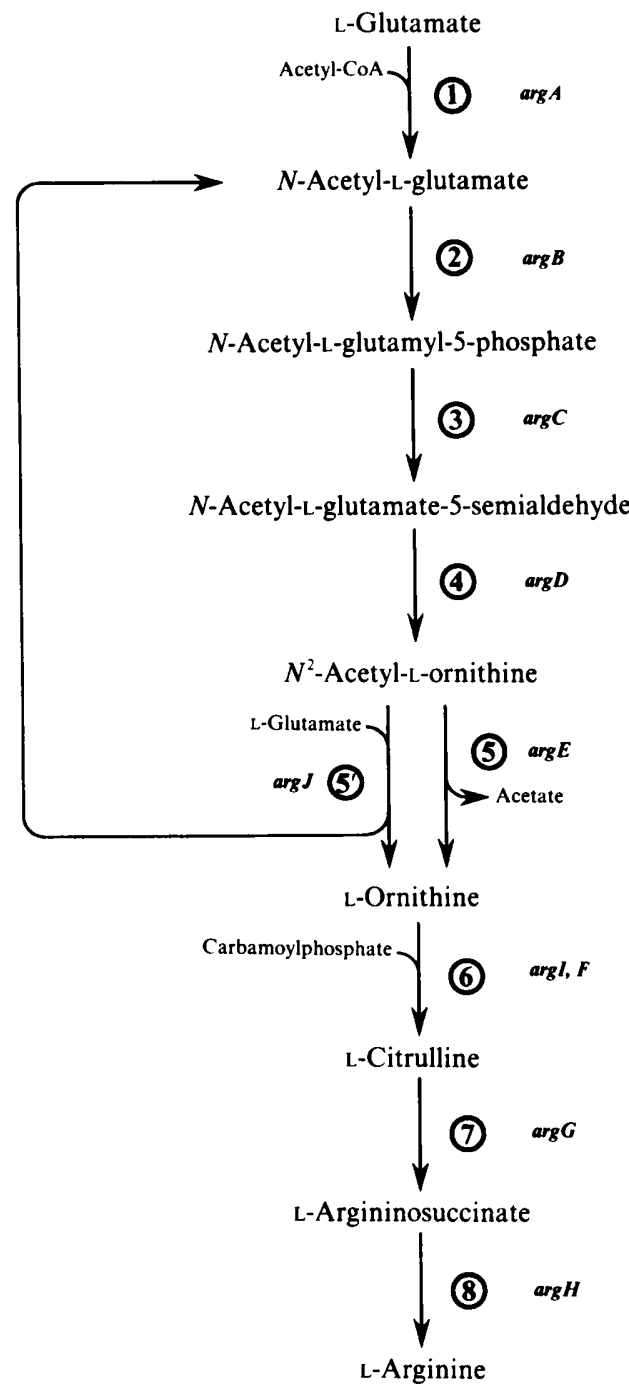

Fig. 1. Arginine biosynthesis. 1, $N$-Acetylglutamate synthase (acetylCoA :L-glutamate $N$-acetyltransferase; EC 2.3.1.1);2, $N$-acetylglutamate 5-phosphotransferase (ATP: $N$-acetyl-L-glutamate 5-phosphotransferase; EC 2.7.2.8); 3, N-acetylglutamate 5-semialdehyde dehydrogenase [ $N$-acetyl-L-glutamate 5-semialdehyde : NADP+ oxidoreductase (phosphorylating); EC 1.2.1.38]; 4, $N^{2}$-acetylornithine 5aminotransferase $\left(N^{2}\right.$-acetyl-L-ornithine : 2 -oxoglutarate aminotransferase; EC 2.6.1.11); 5 acetylornithinase ( $N^{2}$-acetyl-L-ornithine amidohydrolase; EC 3.5.1.16); $5^{\prime}$, ornithine acetyltransferase $\left(N^{2}\right.$-acetylL-ornithine : L-glutamate $N$-acetyltransferase; EC 2.3.1.35); 6, ornithine carbamoyltransferase (carbamoylphosphate:L-ornithine carbamoyltransferase; EC 2.1.3.3); 7, argininosuccinate synthetase [L-citrulline : L-aspartate ligase (AMP-forming); EC 6.3.4.5]; 8, argininosuccinase (L-argininosuccinate arginine-lyase; EC 4.3.2.1).

Restriction enzymes were obtained from the Scientific Industrial Association (Vilnius, Lithuania) or from Pharmacia, and used according to the manufacturer's recommendations.

Enzyme assays. Cells from exponential phase cultures (about $6 \times 10^{8}$ cells $\left.\mathrm{ml}^{-1}\right)$ were harvested by centrifugation $(10 \mathrm{~min}, 7000 \mathrm{~g})$ and washed in $0.9 \% \mathrm{NaCl}$. Cells were suspended in $10 \mathrm{~mm}$-potassium phosphate buffer (pH 6.5) containing $15 \%(\mathrm{v} / \mathrm{v})$ glycerol, $1 \mathrm{~mm}$-EDTA, $1 \mathrm{~mm}$-dithiothreitol and $2 \mathrm{mM}$-phenylmethylsulphonyl fluoride for $\mathrm{N}$ acetylglutamate synthase and ornithine acetyltransferase assays or in 20 mM-potassium phosphate buffer ( $\mathrm{pH} \mathrm{7.5)} \mathrm{for} \mathrm{the} \mathrm{other} \mathrm{assays.} \mathrm{Cells}$ were disrupted by sonication for $10 \mathrm{~min}$. The resulting extracts were centrifuged $(15 \mathrm{~min}, 20000 \mathrm{~g})$ and passed through Sephadex G-25 columns equilibrated with extraction buffer. All these operations were done below $10^{\circ} \mathrm{C}$. B. stearothermophilus enzymes were assayed at $55^{\circ} \mathrm{C}$, E. coli, B. subtilis and B. licheniformis enzymes at $37^{\circ} \mathrm{C}$.

$\mathrm{N}$-Acetylglutamate synthase and ornithine acetyltransferase were assayed as described in Van de Casteele et al.(1990), except that $15 \%$ (v/v) glycerol, $10 \mathrm{~mm}-\mathrm{MgCl}_{2}$ and $7 \mathrm{~mm}$-aminooxyacetic acid were added to the incubation mixture. Aminooxyacetic acid was added in order to reduce the transamination of glutamate in crude extracts.

$\mathrm{N}$-Acetylglutamate 5-phosphotransferase was measured by the ferric chloride method according to Van de Casteele et al. (1990).

Acetylornithinase was measured by the method of Vogel \& McLellan (1970).

$\beta$-Lactamase activity was determined by a microiodometric assay as described by Ross \& O’Callaghan (1975).

One enzyme unit is defined as the amount of enzyme that converts $1 \mu \mathrm{mol}$ substrate to product $\mathrm{h}^{-1}$. Protein concentrations were determined by the Lowry method.

The apparent $K_{\mathrm{m}}$ values for $N^{2}$-acetyl-L-ornithine of ornithine acetyltransferase and acetylornithinase were determined using Lineweaver-Burk and Hanes-Woolf plots.

\section{Results}

\section{Cloning of B. stearothermophilus arg genes}

In a previous communication, Sakanyan et al. (1990) showed that a $3.4 \mathrm{~kb}$ EcoRI fragment of $B$. stearothermophilus DNA (strain NCIB 8224), when inserted in either orientation in plasmid pBR322, complemented E. coli mutants deficient in any of the following enzymes: $N$ acetylglutamate synthase (encoded by $\arg A$ ), $N$-acetylglutamate 5-phosphotransferase (encoded by $\arg B$ ) or acetylornithinase (encoded by $\arg E$ ). From the complementation pattern of various subfragments of the cloned DNA generated by partial Sau3A digestion of the parent plasmid, the order of the functional units (using $E$. coli symbols) was shown to be A-E-B (ibid.).

To locate the genes more precisely on the $3.4 \mathrm{~kb}$ fragment we proceeded to the subcloning experiments summarized in Fig. 2. Using the Pst $\mathrm{I}$ site present $0.5 \mathrm{~kb}$ from the proximal end of the $3.4 \mathrm{~kb} E c o \mathrm{RI}$ fragment cloned in plasmid pAVK1 (Sakanyan et al., 1990) and the pBR322-borne PstI site, we constructed plasmid pAVK 4 which was found to still complement $\arg A, \arg B$ and $\arg E E$. coli auxotrophs. In a second stage, fragments obtained by the simultaneous restriction of pAVK 4 by PstI and PvuII were ligated to plasmid pUC8 DNA digested by $P$ stI and HindII, and the ligation products were used to select $\mathrm{Arg}^{+} \mathrm{Ap}^{\mathrm{r}}$ transformants of $E$. coli arg $E$ mutant MA102. The structure of one such product, pAVK7, is shown in Fig. 2. This plasmid still comple- 
Table 1. Bacterial strains and plasmids

\begin{tabular}{|c|c|c|}
\hline Strain or plasmid & Relevant genotype or phenotype & Source or reference* \\
\hline \multicolumn{3}{|l|}{ E. coli $\mathrm{K} 12$} \\
\hline MA101 & $\mathrm{F}^{-} \arg A$ met $\sup E \sup D$ lac $Z$ hsdR hsdM & M Actuatsaturvana \\
\hline MA102 & $\mathrm{F}^{-}$argE thr leu pro his thi recA $r p s L$ ara & V. Astralsaturyant" \\
\hline XS1D2 & $\mathrm{F}^{-} \Delta 101(p p c-\arg E)$ nalA $r p o B \lambda^{-} h s d R$ & S. Baumberg ${ }^{b}$ \\
\hline $\mathrm{XS} 1 \mathrm{D} 2 r e c A$ & as XS1D2, but recA & This work \\
\hline $\begin{array}{l}\text { XB25 } \\
\text { XA4 }\end{array}$ & $\begin{array}{l}\mathrm{F}^{-} \arg B \text { nal } A \lambda^{-} \lambda^{\mathrm{s}} h s d R \\
\mathrm{~F}^{-} \arg A \text { nal } A \lambda^{-} \lambda^{\mathrm{s}} h s d R\end{array}$ & S. Baumberg ${ }^{b}$ \\
\hline $\begin{array}{l}\text { XA4 } \\
\text { XA4argE }\end{array}$ & $\begin{array}{l}\mathrm{F}^{-} \arg A \text { nal } A \lambda^{-} \lambda^{\mathrm{s}} h s d R \\
\text { as XA4, but } \arg E 86:: \operatorname{Tn} 10\end{array}$ & This work \\
\hline BW6165 & $\begin{array}{l}\operatorname{ara41} \operatorname{lac} Y 1 \lambda^{\text {ind }}-x y l 7 \mathrm{mt} / 2 \\
\arg E 86:: \operatorname{Tn} 10\end{array}$ & Wanner (1986) \\
\hline NK6659 & $\begin{array}{l}\text { Hfr K } 116 \text { his thr relA rpsL srl : } \mathrm{Tn} 10 \\
\operatorname{rec} A\end{array}$ & Laboratory collection \\
\hline \multicolumn{3}{|l|}{ Bacillus } \\
\hline $\begin{array}{l}\text { B. stearothermophilus NCIB } \\
8224\end{array}$ & Prototroph & $\begin{array}{l}\text { All Union Collection of } \\
\text { Microorganisms, Moscow, USSR }\end{array}$ \\
\hline B. subtilis $\mathrm{C} 4$ & Prototroph & I. C. Gunsalus ${ }^{c}$ \\
\hline B. licheniformis ATCC 14580 & Prototroph & $\begin{array}{l}\text { American Type Culture } \\
\text { Collection }\end{array}$ \\
\hline \multicolumn{3}{|l|}{ Plasmid } \\
\hline pAVKI & $A p^{r} T c^{r}$ & Sakanyan et al. (1990) \\
\hline pAVK4 & $\mathrm{Tc}^{r}$ & This work \\
\hline pAVK 7 & $\mathrm{Ap}^{r}$ & 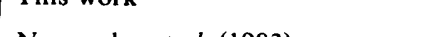 \\
\hline pUC8 & Ap ${ }^{r}$ & Norrander et al. (1983) \\
\hline
\end{tabular}

* Addresses : $a$, M. Astvatsaturyan, Pharmagen, Yerevan, Republic of Armenia ; $b$, S. Baumberg, University of Leeds, UK ; $c$, I. C. Gunsalus, University of Illinois, Urbana, Ill, USA.

ments $\arg A$ and $\arg E E$. coli auxotrophs, but no longer complements $\arg B$ mutants. The $\arg A / \arg E$ complementing activity is therefore encoded by the $2.0 \mathrm{~kb}$ chromosomal fragment carried by pAVK 7 .

We could also show that both pAVK 1 and $\mathrm{pAVK} 7$ are able to efficiently complement the deficiencies of $E$. coli $\mathrm{XA} 4 \arg E$, a double $\arg A \arg E$ mutant (see generation times of the complemented strains in Table 2).

\section{Expression of cloned B. stearothermophilus genes}

Preliminary experiments showed that the acetylornithinase activity of $E$. coli MA102 (carrying a point mutation in the $\arg E$ gene) transformed into an arginine prototroph by plasmid pAVK 1 did not exceed the background level (Sakanyan et al., 1990). This suggested either that pAVK 1 encodes an acetylornithinase which is highly unstable in its new cytoplasmic environment, or that the cloned gene of $\boldsymbol{B}$. stearothermophilus codes for an alternative ornithine-forming function, e.g. an ornithine acetyltransferase activity. In order to distinguish between these possibilities, both acetylornithinase and ornithine acetyltransferase activities were assayed. Cell extracts of $E$. coli XS1D2 (deleted for the arg $E$ gene) carrying pAVK1 or pAVK7 were used. Ornithine acetyltransferase activity was detected in both these two strains, whereas no acetylornithinase could be measured. The ornithine acetyltransferase activities given in Table
2 were measured at $55^{\circ} \mathrm{C}$ (optimal growth temperature of the B. stearothermophilus strain used in this work). When assayed at $37^{\circ} \mathrm{C}$ this activity was about threefold lower. Addition of arginine to the growth medium did not significantly affect the activity. The $\beta$-lactamase levels were similar in these conditions (Table 2) as expected for similar plasmid copy numbers. The apparent $K_{\mathrm{m}}$ value of ornithine acetyltransferase for $N^{2}$-acetyl$\mathrm{L}$-ornithine at $10 \mathrm{~mm}$-glutamate was $0.3 \mathrm{~mm}$ (measured on dialysed crude extract of strain XS1D2 carrying the pAVK 7 plasmid).

In an $E$. coli $\arg A \arg E$ double mutant (strain $\mathrm{XA4}$ argE) transformed to arginine prototrophy by pAVK 1 or pAVK 7 DNA, both the $N$-acetylglutamate synthase and the ornithine acetyltransferase activities encoded by the $B$. stearothermophilus genes were expressed (Table 2). However, addition of arginine to the culture medium led to a drastic decrease of enzyme levels in strain XA4argE carrying pAVK 7. The very low level of $\beta$-lactamase in this culture (Table 2) indicates that plasmid pAVK7 becomes very unstable in $E$. coli $\mathrm{XA} 4 \arg E$ when the only selective pressure applied is resistance to ampicillin.

Analysis of enzyme activities in B. stearothermophilus

The above results suggest that the cloned $B$. stearothermophilus gene that complements $E$. coli arg $E$ mutations 


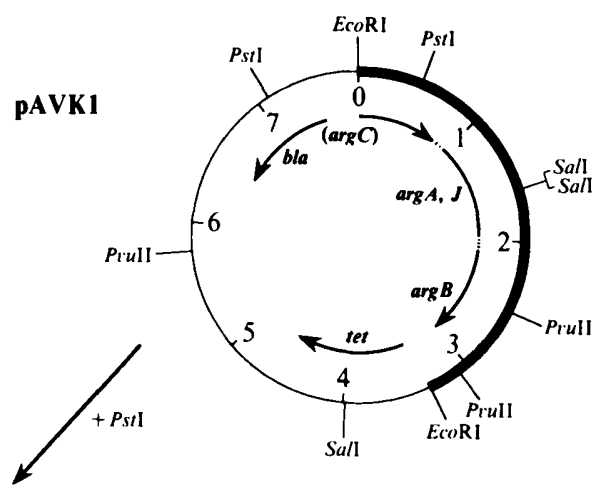

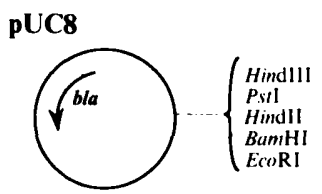

+ Pstl:HindII
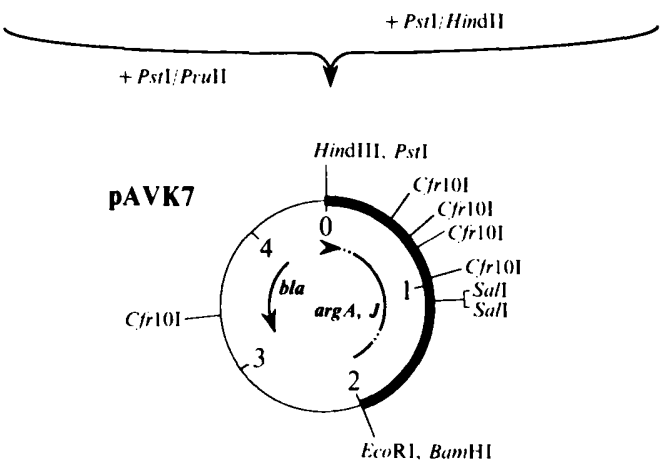

Fig. 2. Cloning of $B$. stearothermophilus arg genes. The recombinant plasmids contain chromosomal DNA from B. stearothermophilus strain NCIB 8224 (heavy lires) inserted into the vector pBR322 (thin lines) for plasmids $\mathrm{pAVK} 1$ and $\mathrm{pAVK} 4$ and into the vector pUC8 (thin lines) for plasmid pAVK7. The map shows the locations of the arg genes and the direction of transcription for $\arg C$ (the plasmids contain only part of this gene) and $\arg B$, as deduced from the sequence homology with $E$. coli $\arg C$ and $\arg B$ genes (unpublished results). codes for an ornithine acetyltransferase rather than an acetylornithinase. It was therefore of interest to examine the pathway for ornithine synthesis in $B$. stearothermophilus. $\mathrm{N}$-Acetylglutamate synthase, $\mathrm{N}$-acetyl 5-phosphotransferase and ornithine acetyltransferase activities were detected in extracts of $B$. stearothermophilus (Table 2). $\mathrm{N}$-Acetyl 5-phosphotransferase and ornithine acetyltransferase synthesis were repressed by arginine [specific activity of $N$-acetyl 5 -phosphotransferase $0.3 \mu \mathrm{mol}$ product $\mathrm{h}^{-1}$ (mg protein $)^{-1}$ in the absence of arginine and 0.07 in the presence of arginine]. The level of $N$ acetylglutamate synthase was not affected by arginine addition. Inhibition of enzyme activity by arginine was tested for the three enzymes by adding L-arginine (concentration range $0.01-100 \mathrm{~mm}$ ) to the reaction mixture of the enzyme assays described above. Arginine was found to inhibit $N$-acetylglutamate synthase and ornithine acetyltransferase, but this inhibition was in both cases limited to $40 \%$. The arginine concentrations for $40 \%$ inhibition were, respectively, 2.5 and $4 \mathrm{~mm}$. The apparent $K_{\mathrm{m}}$ value of ornithine acetyltransferase for $N^{2}$ acetyl-L-ornithine at $10 \mathrm{~mm}$-glutamate was $0.4 \mathrm{~mm}$. This value corresponds closely to the $K_{\mathrm{m}}$ value determined for the pAVK 7-encoded enzyme. An aminoacylase displaying some activity towards $N^{2}$-acetyl-L-ornithine was also found in $B$. stearothermophilus extracts (Table 2). However, the affinity of this enzyme for $N^{2}$-acetyl-Lornithine was very low $\left(K_{\mathrm{m}}>60 \mathrm{mM}\right)$. Moreover, arginine in the culture medium did not affect the level of this activity. This aminoacylase was active towards a broad range of acyl-L-amino acid derivatives; its activity with $N^{2}$-acetyl-L-ornithine as substrate proved much lower than with other acyl derivatives (data not shown). 
Table 2. Specific activities of $N$-acetylglutamate synthase, ornithine acetyltransferase and acetylornithinase in E. coli strains carrying B. stearothermophilus genes and in Bacillus species

Specific activities are means of at least two measurements made on independent cultures. The values for replicate assays differed from the mean by $<20 \%$ for $N$-acetylglutamate synthase and ornithine acetyltransferase, and by $<10 \%$ for acetylornithinase activity. $\beta$-Lactamase was assayed as a plasmid marker. ND, Not determined.

\begin{tabular}{|c|c|c|c|c|c|c|}
\hline \multirow[b]{2}{*}{ Strain } & \multirow{2}{*}{$\begin{array}{l}\text { Arginine } \\
\text { addition to } \\
\text { growth } \\
\text { medium* }\end{array}$} & \multirow[b]{2}{*}{$\begin{array}{l}\text { Generation } \\
\text { time (min) }\end{array}$} & \multicolumn{4}{|c|}{ Enzyme activity [units (mg protein) ${ }^{-1}$ ] } \\
\hline & & & $\begin{array}{c}N \text {-Acetylglutamate } \\
\text { synthase }\end{array}$ & $\begin{array}{c}\text { Ornithine } \\
\text { acetyltransferase }\end{array}$ & $\begin{array}{c}\text { Acetyl- } \\
\text { ornithinase }\end{array}$ & $\beta$-Lactamase \\
\hline E. coli K12 XS1D2 & + & 80 & ND & $<0.001$ & $<0.005$ & $<0.01$ \\
\hline $\begin{array}{l}\text { E. coli K12 } \\
\text { XS1D2(pAVK1) }\end{array}$ & $\overline{+}$ & $\begin{array}{r}100 \\
90\end{array}$ & $\begin{array}{l}\text { ND } \\
\text { ND }\end{array}$ & $\begin{array}{l}0.97 \pm 0.08 \\
0.99 \pm 0.07\end{array}$ & $\begin{array}{l}<0.005 \\
<0.005\end{array}$ & $\begin{array}{l}532 \pm 25 \\
539 \pm 18\end{array}$ \\
\hline $\begin{array}{l}\text { E. coli K12 } \\
\text { XS1D2(pAVK7) }\end{array}$ & $\overline{+}$ & $\begin{array}{l}100 \\
100\end{array}$ & $\begin{array}{l}\text { ND } \\
\text { ND }\end{array}$ & $\begin{array}{l}1 \cdot 77 \pm 0 \cdot 15 \\
1 \cdot 20 \pm 0 \cdot 10\end{array}$ & $\begin{array}{l}<0.005 \\
<0.005\end{array}$ & $\begin{array}{l}653 \pm 24 \\
633 \pm 21\end{array}$ \\
\hline E. coli K 12 XA4argE & + & 70 & $<0.001$ & $<0.001$ & $<0.005$ & ND \\
\hline $\begin{array}{l}\text { E. coli } \mathrm{K} 12 \\
\text { XA4arg } E(\mathrm{pAVK} 1)\end{array}$ & $\overline{+}$ & $\begin{array}{l}87 \\
83\end{array}$ & $\begin{array}{l}0.32 \pm 0.04 \\
0 \cdot 30 \pm 0.04\end{array}$ & $\begin{array}{l}0.71 \pm 0.07 \\
0.67 \pm 0.07\end{array}$ & $\begin{array}{l}<0.005 \\
<0.005\end{array}$ & $\begin{array}{l}449 \pm 22 \\
400 \pm 17\end{array}$ \\
\hline $\begin{array}{l}\text { E. coli } \mathrm{K} 12 \\
\text { XA4argE(pAVK7) }\end{array}$ & $\begin{array}{l}- \\
+\end{array}$ & $\begin{array}{r}154 \\
72\end{array}$ & $\begin{array}{l}0.84 \pm 0.05 \\
0.07 \pm 0.01\end{array}$ & $\begin{array}{l}2.04 \pm 0.18 \\
0 \cdot 10 \pm 0.01\end{array}$ & $\begin{array}{l}<0.005 \\
<0.005\end{array}$ & $\begin{array}{c}1968 \pm 36 \\
32 \pm 4\end{array}$ \\
\hline $\begin{array}{l}\text { B. stearothermophilus } \\
\text { NCIB } 8224\end{array}$ & $\overline{+}$ & $\begin{array}{l}160 \\
160\end{array}$ & $\begin{array}{l}0.04 \pm 0.01 \\
0.04 \pm 0.01\end{array}$ & $\begin{array}{l}0.28 \pm 0.02 \\
0.07 \pm 0.005\end{array}$ & $\begin{array}{l}0.12 \pm 0.02 \\
0.11 \pm 0.02\end{array}$ & $\begin{array}{l}\text { ND } \\
\text { ND }\end{array}$ \\
\hline $\begin{array}{l}\text { B. subtilis } \\
\text { C4 }\end{array}$ & $\overline{+}$ & $\begin{array}{l}51 \\
54\end{array}$ & $\begin{array}{l}0.04 \pm 0.01 \\
0.01 \pm 0.002\end{array}$ & $\begin{array}{c}0.05 \pm 0.005 \\
<0.005\end{array}$ & $\begin{array}{l}<0.005 \\
<0.005\end{array}$ & $\begin{array}{l}\text { ND } \\
\text { ND }\end{array}$ \\
\hline $\begin{array}{l}\text { B. licheniformis } \\
\text { ATCC } 14580\end{array}$ & $\overline{+}$ & $\begin{array}{l}45 \\
42\end{array}$ & $\begin{array}{l}0.04 \pm 0.01 \\
0.01 \pm 0.002\end{array}$ & $\begin{array}{c}0.03 \pm 0.005 \\
<0.005\end{array}$ & $\begin{array}{l}<0.005 \\
<0.005\end{array}$ & $\begin{array}{l}\text { ND } \\
\text { ND }\end{array}$ \\
\hline
\end{tabular}

- Arginine was added at a concentration of $5 \mathrm{mM}$. Succinate $(0.5 \%$, w/v) was added for $E$. coli XS1D2 strains. $E$. coli strains carrying plasmid pAVK1 or pAVK 7 were grown in the presence of Ap.

\section{Acetylornithine deacylation in other Bacillus species}

It has been reported previously that the formation of ornithine from $N^{2}$-acetyl-L-ornithine in $B$. subtilis is mediated by the hydrolytic enzyme acetylornithinase (Vogel \& Vogel, 1963). In the light of the results obtained for $B$. stearothermophilus, the acetylornithine deacylation step was examined in two mesophilic Bacillus species, $B$. licheniformis and $B$. subtilis. No acetylornithinase activity could be detected in the two strains investigated (Table 2). However, a low but significant ornithine acetyltransferase activity could be measured. Addition of arginine to the growth medium led to a strong decrease of both ornithine acetyltransferase and $N$-acetylglutamate synthase activities (Table 2), indicating a biosynthetic function. The apparent $K_{\mathrm{m}}$ value of ornithine acetyltransferase for $N^{2}$-acetyl-L-ornithine at $10 \mathrm{mM}$-glutamate was $0.1 \mathrm{~mm}$ for the $B$. subtilis enzyme and $1 \mathrm{~mm}$ for that of B. licheniformis.

\section{Discussion}

The enzyme assays performed with extracts prepared from $E$. coli arg $E$ mutants (defective in acetylornithinase activity) carrying plasmid pAVK 1 or pAVK 7 disclosed a high ornithine acetyltransferase activity, but no acetylor- nithinase activity. This provides evidence that an ornithine acetyltransferase encoded by a $B$. stearothermophilus gene can replace acetylornithinase in $E$. coli. The same observation was already reported for the argJ gene of Neisseria gonorrhoeae (Picard \& Dillon, 1989). The involvement of an ornithine acetyltransferase in the arginine biosynthetic pathway of a Bacillus strain was, however, unexpected, since Bacillaceae have been reported to use the linear pathway proceeding via the hydrolytic enzyme acetylornithinase (Vogel \& Vogel, 1963; Udaka, 1966). Re-examination of the acetylornithine deacylation step in two mesophilic Bacillus species, $B$. licheniformis and $B$. subtilis, led us to the conclusion that these organisms too recycle the acetyl group from $N^{2}$-acetyl-L-ornithine to glutamate. The gene encoding this enzyme in these three Bacillus species (and presumably other ones as well) should thus be referred to as arg $J$ rather than $\arg E$.

The acetylornithinase activity previously reported for a $B$. subtilis strain (Vogel \& Vogel, 1963) could result from the action of a broad substrate specificity aminoacylase or peptidase such as those described by Cho et al. (1987, 1988). Such an aspecific acetylornithine deacylase activity was previously reported in yeast (Degryse, 1974) and in two strains of extreme thermophilic bacteria, Thermus aquaticus and Thermotoga maritima, which synthesize arginine by the cyclic pathway (Van de 
Casteele et al., 1990). The B. stearothermophilus strain used in this work also possesses an aminoacylase activity. The gene encoding this enzyme has been cloned into $E$. coli by complementation of an $\arg E$ deficiency (unpublished results).

The cloned arg genes of $B$. stearothermophilus are arranged in the same order as in $B$. subtilis, i.e. arg $C-A-J$ $B$ (Mountain et al., 1986; Sakanyan et al., 1990). Partial sequencing of the bacterial DNA carried by plasmid pAVK1 indeed revealed the presence of a sequence homologous to the carboxy-terminal part of the $E$. coli $\arg C$ gene at the proximal end and of a complete $\arg B$ gene at the distal end (unpublished results). From these data it appears that the $\arg A / \arg E$ complementing activity is encoded by no more than $1350 \mathrm{bp}$ located between $\arg C$ and $\arg B$. The size of this fragment is about the same as that determined for the $E$. coli $\arg A$ gene (1332 bp; Brown et al., 1987). One may thus ask whether the products of the $B$. stearothermophilus arg $A$ and arg $J$ genes are two distinct proteins as in Pseudomonas (Haas et al., 1977) or if both activities are the property of a single enzyme as suggested for the alga Chlorella vulgaris (Morris \& Thompson, 1975) and for Neisseria gonorrhoeae (Picard \& Dillon, 1989). A detailed functional analysis of the relevant sequence will be needed to answer this question.

We thank M. Demarez for excellent technical assistance. This work was supported by the Belgian Fund for Joint Research (contract 2.9003.88), by a Concerted Research Action between the French and Flemish Communities and the cognate Free Universities of Brussels, and by the Flemish Action Program for Biotechnology. V.S. gratefully acknowledges the financial support of the Flemish Community and the Vrije Universiteit Brussel during his visit to Belgium. N.G. thanks the Belgian National Foundation for Scientific Research and the Pharmagen Laboratory in Yerevan for supporting his visit to the Republic of Armenia.

\section{References}

Brown, K., Finch, P. W., Hickson, I. D. \& Emmerson, P. T. (1987). Complete nucleotide sequence of the Escherichia coli $\arg A$ gene. Nucleic Acids Research 15, 10586.

Birnbolm, H. C. \& Doly, J. (1979). A rapid alkaline extraction procedure for screening recombinant DNA. Nucleic Acids Research 7, 1513-1523.

Cho, H. Y., Tanizawa, K., Tanaka, H. \& Soda, K. (1987). Thermostable aminoacylase from Bacillus thermoglucosidus: purification and characterization. Agricultural and Biological Chemistry 51, 2793-2800.

Cho, H. Y., Tanizawa, K., Tanaka, H. \& Soda, K. (1988). Thermostable dipeptidase from Bacillus stearothermophilus: its purification, characterization, and comparison with aminoacylase. Journal of Biochemistry 103, 622-628.

DAGERT, M. \& EHRLICH, S. D. (1979). Prolonged incubation in calcium chloride improves the competence of $E$. coli cells. Gene 6, 23-28.

DAvis, R. H. (1986). Compartmental and regulatory mechanisms in the arginine pathways of Neurospora crassa and Saccharomyces cerevisiae. Microbiological Reviews 50, 280-313.

DEGRYSE, E. (1974). Evidence that yeast acetylornithinase is a carboxypeptidase. FEBS Letters 43, 285-288.

Falmagne, P., Vanderwinkel, E. \& Wiame, J. M. (1965). Mise en évidence de deux malate synthétases chez Escherichia coli. Biochimica et Biophysica Acta 99, 246-258.

haAs, D., Holloway, B. W., Schambock, A. \& Leisinger, T. (1977). The genetic organization of arginine biosynthesis in Pseudomonas aeruginosa. Molecular and General Genetics 154, 7-22.

Jeenes, D. J., Soldati, L., Baur, H., Watson, J. M., Mercenier, A., ReimmanN, C., Leisinger, T. \& HaAs, D. (1986). Expression of biosynthetic genes from Pseudomonas aeruginosa and Escherichia coli in heterologous hosts. Molecular and General Genetics 203, 421-429.

Maniatis, T., Fritsch, E. F. \& SAmbroOK, J. (1982). Molecular Cloning. A Laboratory Manual. Cold Spring Harbor, NY: Cold Spring Harbor Laboratory.

MEILE, L. \& LeISINGER, T. (1984). Enzymes of arginine biosynthesis in methanogenic bacteria. Experientia 40, 899-900.

MoRRIs, C. J. \& THOMPSON, J. F. (1975). Acetyl coenzyme-A glutamate acetyltransferase and $N^{2}$-acetylornithine acetyltransferase of Chlorella. Plant Physiology 55, 960-967.

Mountain, A., ManN, N. H., Munton, R. N. \& Baumberg, S. (1984). Cloning of Bacillus subtilis restriction fragment complementing auxotrophic mutants of eight Escherichia coli genes of arginine biosynthesis. Molecular and General Genetics 197, 82-89.

Mountain, A., McChesney, J., Smith, M. C. M. \& Baumberg, S. (1986). Gene sequence encoding early enzymes of arginine synthesis within a cluster in Bacillus subtilis, as revealed by cloning in Escherichia coli. Journal of Bacteriology 165, 1026-1028.

Norrander, J., Kempe, T. \& Messing, J. (1983). Construction of M13 vectors using oligodeoxynucleotide-directed mutagenesis. Gene 26, 101-106.

PiCard, F. J. \& Dillon, J. R. (1989). Cloning and organization of seven arginine biosynthesis genes from Neisseria gonorrhoeae. Journal of Bacteriology 171, 1644-1651.

PiÉRARD, A. \& WiAME, J. M. (1964). Regulation and mutation affecting a glutamine dependent formation of carbamylphosphate in Escherichia coli. Biochemical and Biophysical Research Communications 15, 76-81.

Ramaley, R. F. \& Hixson, J. (1970). Isolation of a nonpigmented, thermophilic bacterium similar to Thermus aquaticus. Journal of Bacteriology 103, 527-528.

Ross, G. W. \& O'Callaghan, C. H. (1975). $\beta$-Lactamase assays. Methods in Enzymology 43, 69-85.

Sakanyan, V. A., Hovsepyan, A. S., Mett, I. L., Kochikyan, A. V. \& Petrosyan, P. K. (1990). Molecular cloning and structuralfunctional analysis of the arginine biosynthesis genes of the thermophilic bacterium Bacillus stearothermophilus. Genetika (USSR) 26, 1915-1925.

Stalon, V., Ramos, F., Piérard, A. \& Wiame, J. M. (1967). The occurrence of a catabolic and an anabolic ornithine carbamoyltransferase in Pseudomonas. Biochimica et Biophysica Acta 139, 91-97.

UDAKA, S. (1966). Pathway-specific pattern of control of arginine biosynthesis in bacteria. Journal of Bacteriology 91, 617-621.

Van de Casteele, M., Demarez, M., Legrain, C., GlansdorfF, N.\& PiÉrard, A. (1990). Pathways of arginine biosynthesis in extreme thermophilic archaeo- and eubacteria. Journal of General Microbiology 136, 1177-1183.

VOGEL, H. J. \& BONNER, D. M. (1956). Acetylornithinase of Escherichia coli: partial purification and some properties. Journal of Biological Chemistry 218, 97-106.

Vogel, H. J. \& MCLellan, W. L. (1970). Acetylornithinase (Escherichia coli). Methods in Enzymology 17A, 265-269.

VoGEL, R. H. \& VoGEL, H. J. (1963). Acetylated intermediates of arginine synthesis in Bacillus subtilis. Biochimica et Biophysica Acta 69, 174-176.

WANNER, B. L. (1986). Novel regulatory mutants of the phosphate regulon in Escherichia coli K-12. Journal of Molecular Biology 191, 3958. 